\title{
Efficiency Measurement of Kenyan Commercial Banks
}

\section{Isaiah Onsarigo Miencha}

Ph.D Research Scholar, Department of Commerce and Financial Studies, Bharathidasan University, Tiruchirappalli- 620 024, Tamil Nadu, India

Email: isaiahmnch@gmail.com

\section{Professor Selvam Murugesan}

Professor and Head, Department of Commerce and Financial Studies, Bharathidasan University, Tiruchirappalli- 620 024, Tamil Nadu, India

\section{Vinayagamoorthi Vasanth}

Ph.D Research Scholar, Department of Commerce and Financial Studies, Bharathidasan University, Tiruchirappalli- 620 024, Tamil Nadu, India

\section{Kasilingam Lingaraja}

Ph.D Research Scholar, Department of Commerce and Financial Studies, Bharathidasan University, Tiruchirappalli- 620 024, Tamil Nadu, India

\author{
Mariappan Raja \\ Assistant Professor, Department of Commerce, Bharathidasan University Constituent College, \\ Lalgudi - 621 601, Tamil Nadu State, India
}

Doi:10.5901/mjss.2015.v6n4s2p621

\section{Abstract}

The idea of development is considered a vital strategy to the growth of any national economy. The banking system has been considered as the main sector that contributes significantly to the development of economy and hence the efficiency of commercial banks, gains significance. This study proposes to examine the efficiency of Private and Public Sector Banks in Kenya. It was found that the sample Kenyan commercial banks recorded volatility of variables during the study period. But the Public Sector Banks displayed better efficiency scores than the Private Sector Banks during the study period.

Keywords: Kenyan Commercial Banks, Banking Industry, Data Envelopment Analysis.

\section{Introduction}

It has been recognized that the financial system in Africa in general and Kenya specifically, is shallow and fragile and therefore, it failed to fulfill the real economic objectives of growth and poverty eradication in Africa (Nissanke and Stein, 2003). The shallowness and fragility are reflected in low lending levels, high interest rate spreads, high levels of nonperforming loans and several bank failures. However, financial institutions, particularly commercial banks, play a vital role in the economy of any developing nation (King and Levine, 1993). As one of the fast growing economies in the world, Kenya experiences a slight increase in the expectations of the business partners. The banking sector in Kenya faced serious functional problems during the past few decades. Commercial banks have been undergoing tremendous technological and managerial changes due to globalization and dynamic environment. Though the financial system in Kenya had an advantage in operating in closed and regulated environment, it went through a sea change during the nineties (Mkandawire, T. 1999).

The Central Bank of Kenya (CBK), besides initiating many reforms such as de-regulation, use of technology, delicensing etc, decided to establish five banks on a national basis (National Banks), with a network throughout the country. Besides, computerization of banking operations was stepped up. Foreign banks, operating in Kenya, were subjected to the requirements as applicable to domestic banks. These reforms created competitiveness and immense pressure in the banking industry and it triggered greater use of information technology, consumer credit, more transparent balance sheet 
and product diversification. The reforms have also raised concerns about the efficiency of Kenyan banking system, especially due to the Non-Performing Assets (NPAs). In the current competitive atmosphere, commercial banks are under pressure to make credit more affordable and expand their lending portfolio, to reverse the slowdown and spur the growth. The competitive service quality in the cutthroat competition is important for survival and the existence of any banking institution. The effectiveness of institutions is to be measured in terms of efficiency and competitive edge over others. Therefore, an analysis of banks' efficiency is crucial to the markets, the Government and the society. Commercial banks are constantly trying to achieve international benchmarks, with the help of best practices. Private banks in Kenya performed well, with better liquidity assets, compared to public banks and foreign banks. The study by Miencha, et al (2013) found that the relative average efficiency score for all sample banks, over the years, was fair.

\section{Literature Review}

Extensive research has been conducted on the banking sector in the global context. Some of them have worked on banking efficiency measurement. An attempt has been made in this paper to review the previous studies. The summarized results of reviews, relevant to this study, are given in Table-1.

Table 1. Summary of Recent Studies on Banks' Efficiency Evaluation

\begin{tabular}{|c|c|c|c|c|c|}
\hline Author(s) and Year(s) & Methodology & Units- DMUs & Inputs & Outputs & Findings \\
\hline Charnes et al (1978) & DEA-CCR & & & & $\begin{array}{l}\text { Employed a CCR model to measure the } \\
\text { technical efficiency which was based on the } \\
\text { concept of the Pareto optimum. }\end{array}$ \\
\hline $\begin{array}{l}\text { Banker, Charnes and } \\
\text { Cooper (1984) }\end{array}$ & DEA-BCC & & & & $\begin{array}{l}\text { Used DEA to identify the most efficient Decision } \\
\text { Making Unit (DMU) among all DMUs. }\end{array}$ \\
\hline $\begin{array}{l}\text { Tser-Yieth Chen and } \\
\text { Yeh (2000) }\end{array}$ & DEA & $\begin{array}{l}34 \text { Taiwan } \\
\text { Commercial } \\
\text { banks }\end{array}$ & $\begin{array}{l}\text { 1-Deposits } \\
\text { 2-Assets }\end{array}$ & $\begin{array}{l}\text { 1-Investments } \\
\text { 2-Interest Income }\end{array}$ & $\begin{array}{l}\text { Increase in staff salaries and market } \\
\text { competition made it is difficult for the sample } \\
\text { banks difficult to improve technical efficiency. }\end{array}$ \\
\hline $\begin{array}{l}\text { David A. Grigorian and } \\
\text { Vlad Manole (2002), }\end{array}$ & DEA & & $\begin{array}{l}\text { 1-Personnel and } \\
\text { Management } \\
\text { 2-Computor } \\
\text { hardware and } \\
\text { premises } \\
\text { 3-Leverage funds }\end{array}$ & $\begin{array}{l}\text { 1-Revenues } \\
\text { 2-Net loans } \\
\text { 3-Liquid assets } \\
\text { 4-Deposits }\end{array}$ & $\begin{array}{l}\text { It was found that some banking sectors } \\
\text { experienced major transformation throughout } \\
\text { the study period while some countries have } \\
\text { been successful in eliminating underlying } \\
\text { distortions and restructuring their financial } \\
\text { sectors. }\end{array}$ \\
\hline $\begin{array}{l}\text { Wang and Huang } \\
(2005)\end{array}$ & DEA-CCR & $\begin{array}{l}\text { Top } 200 \text { banks in } \\
\text { China }\end{array}$ & $\begin{array}{l}\text { 1- Capital } \\
\text { 2-Total assets }\end{array}$ & $\begin{array}{l}\text { 1-ROE } \\
\text { 2-ROA }\end{array}$ & $\begin{array}{l}\text { According to CCR efficiency score analysis, two } \\
\text { sample banks were relatively efficient. Private } \\
\text { banks recorded higher efficiency than state- } \\
\text { owned banks. }\end{array}$ \\
\hline Debasish, S.S. (2006), & DEA- CRR & Indian Banks & & & $\begin{array}{l}\text { The study found that there was concentration of } \\
\text { efficiency parameters among peer bank groups } \\
\text { during the study period. }\end{array}$ \\
\hline Asmild et al (2006) & DEA & $\begin{array}{l}\text { Large Canadian } \\
\text { Banks }\end{array}$ & & & $\begin{array}{l}\text { It was found that knowledge of this relationship } \\
\text { enabled the evaluation of productivity of } \\
\text { completed projects and in particular, it provided } \\
\text { a predictive tool for future projects. }\end{array}$ \\
\hline $\begin{array}{l}\text { Avkran, and Rowlands } \\
(2008)\end{array}$ & DEA models & & & & $\begin{array}{l}\text { It was found that there was a comprehensive } \\
\text { approach where total input and output slacks } \\
\text { were identified simultaneously for non-radial } \\
\text { inefficiencies before leveling the playing field, } \\
\text { identifying percent adjustments attributable to } \\
\text { the environment and statistical noise and using } \\
\text { a fully units-invariant DEA model. }\end{array}$ \\
\hline $\begin{array}{l}\text { Debnath and } \\
\text { Ravishankar } \\
(2008)\end{array}$ & $\begin{array}{l}\text { CCR and } \\
\text { BCC model }\end{array}$ & 50 Indian banks & $\begin{array}{l}\text { 1-Total assets 2- } \\
\text { Deposits }\end{array}$ & $\begin{array}{l}\text { 1-PAT } \\
\text { 2-Operating profit } \\
\text { 3-Interest income 4- } \\
\text { Advances } \\
\text { 5-Net non- } \\
\text { performing assets 6- } \\
\text { Total income } \\
\end{array}$ & $\begin{array}{l}\text { Identified the priority areas for banks which } \\
\text { could improve the efficiency in India. }\end{array}$ \\
\hline Giokas (2008) & DEA & $\begin{array}{l}171 \text { commercial } \\
\text { bank branches of } \\
\text { Greece }\end{array}$ & $\begin{array}{l}\text { 1-Borrowings 2- } \\
\text { Deposits } \\
\text { 3-Fixed assets } \\
\text { 4-Net worth } \\
\text { 5-Operating } \\
\text { expenses }\end{array}$ & $\begin{array}{l}\text { 1-Advances } \\
\text { 2-Loans } \\
\text { 3-Investment } \\
\text { 4-Net interest } \\
\text { income }\end{array}$ & $\begin{array}{l}\text { The results indicated the scope for substantial } \\
\text { efficiency improvements. }\end{array}$ \\
\hline
\end{tabular}




\begin{tabular}{|c|c|c|c|c|c|}
\hline Kyriaki et al. (2008) & DEA & 19 Greek Banks & Deposits & Total Assets & $\begin{array}{l}\text { Though small banks seem to be more efficient } \\
\text { and vulnerable, large ones have lower } \\
\text { operating costs due to the scale economies and } \\
\text { their network. }\end{array}$ \\
\hline Saha (2008) & Descriptive & $\begin{array}{l}4 \text { Large } \\
\text { Bangladesh } \\
\text { banks }\end{array}$ & $\begin{array}{l}\text { 1-Total Advances } \\
\text { 2-Total } \\
\text { Investments } \\
\text { 3-Total Income } \\
\text { Net profit }\end{array}$ & Total Deposits & $\begin{array}{l}\text { It was found that the commercial banks in } \\
\text { Bangladesh showed greater fluctuation in } \\
\text { profitability and productivity during the study } \\
\text { period. }\end{array}$ \\
\hline $\begin{array}{l}\text { Satya Paul and } \\
\text { Khaled Kourouche } \\
(2008)\end{array}$ & $\begin{array}{l}\text { BCC and } \\
\text { CCR model- } \\
\text { scale } \\
\text { efficiencies }\end{array}$ & $\begin{array}{l}10 \text { Australian } \\
\text { banks for } 1997\end{array}$ & $\begin{array}{l}\text { 1-Interest } \\
\text { expense } \\
\text { 2-Non-interest } \\
\text { expense }\end{array}$ & $\begin{array}{l}\text { 1-Net interest } \\
\text { income } \\
\text { 2-Non-interest } \\
\text { income }\end{array}$ & $\begin{array}{l}\text { The extent of TE varied across the banks and } \\
\text { over the years. }\end{array}$ \\
\hline $\begin{array}{l}\text { Supachet Chansan } \\
(2008)\end{array}$ & DEA & $\begin{array}{l}13 \text { Thai } \\
\text { Commercial } \\
\text { Banks }\end{array}$ & $\begin{array}{l}\text { 1-Interest } \\
\text { Expenses } \\
\text { 2-Labor related } \\
\text { expenses } \\
\text { 3-Capital related } \\
\text { expenses }\end{array}$ & $\begin{array}{l}\text { 1-Interest and } \\
\text { dividend incomes } \\
\text { 2-Non-interest } \\
\text { incomes. }\end{array}$ & $\begin{array}{l}\text { It was found that the efficiency of Thai } \\
\text { commercial via operation approach was very } \\
\text { stable while the efficiency via intermediation } \\
\text { approach was moderately and somewhat } \\
\text { volatile. }\end{array}$ \\
\hline $\begin{array}{l}\text { Kumar and Gulati } \\
(2008)\end{array}$ & $\begin{array}{l}\text { CCR DEA } \\
\text { model }\end{array}$ & $\begin{array}{l}27 \text { PSB's for } \\
2006-07\end{array}$ & $\begin{array}{l}\text { 1-Physical capital } \\
\text { 2-Labour } \\
\text { 3-Loanable funds }\end{array}$ & $\begin{array}{l}\text { 1- Investment } \\
\text { 2- Advances }\end{array}$ & $\begin{array}{l}\text { The high efficiency did not stand for high } \\
\text { effectiveness in public banks. }\end{array}$ \\
\hline Luo and Yao (2010) & $\begin{array}{l}\text { DEA- } \\
\text { CCR,BCC }\end{array}$ & 14 listed banks & $\begin{array}{l}\text { 1-Deposits } \\
\text { 2-Number of } \\
\text { Employees } \\
\text { 3-Fixed Assets }\end{array}$ & $\begin{array}{l}\text { 1-Investments } \\
\text { 2-Total Assets }\end{array}$ & $\begin{array}{l}\text { The authors adopted the super-efficiency model } \\
\text { to estimate the super-efficiency of Chinese } \\
\text { commercial banks to overcome these difficulties } \\
\text { and found that some variables had significant } \\
\text { impact on efficiency. }\end{array}$ \\
\hline $\begin{array}{l}\text { Sufian and Habibullah } \\
(2010)\end{array}$ & DEA & $\begin{array}{l}\text { Thailand } \\
\text { commercial banks }\end{array}$ & $\begin{array}{l}\text { 1-Deposits } \\
\text { 2-Assets }\end{array}$ & $\begin{array}{l}\text { 1-Loans } \\
\text { 2-Investments } \\
\text { 3-Non-Interest } \\
\text { Income. } \\
\end{array}$ & $\begin{array}{l}\text { According to this study, small Singapore } \\
\text { commercial banks were found to have } \\
\text { outperformed their large and very large peers } \\
\text { during the study period. }\end{array}$ \\
\hline $\begin{array}{l}\text { Miencha and Selvam } \\
(2013)\end{array}$ & $\begin{array}{l}\text { BCC and } \\
\text { CCR model- } \\
\text { scale } \\
\text { efficiencies }\end{array}$ & $\begin{array}{l}10 \text { Kenyan banks } \\
\text { for } 2007-10\end{array}$ & $\begin{array}{l}\text { 1-Interest } \\
\text { expense } \\
\text { 2-Non-interest } \\
\text { expense }\end{array}$ & $\begin{array}{l}\text { 1-Net interest } \\
\text { income } \\
\text { 2-Non-interest } \\
\text { income }\end{array}$ & $\begin{array}{l}\text { The extent of TE and SE varied across the } \\
\text { commercial Kenyan banks over the study } \\
\text { period. }\end{array}$ \\
\hline $\begin{array}{l}\text { Robert DeYoung and } \\
\text { Iftekhar Hasan (2013) }\end{array}$ & & $\begin{array}{l}\text { US Commercial } \\
\text { Banks }\end{array}$ & $\begin{array}{l}\text { 1-Total assets } \\
\text { 2-Firm size } \\
\text { 3-Market to book }\end{array}$ & $\begin{array}{l}\text { 1-Loans } \\
\text { 2-Non-interest } \\
\text { 3-Investment }\end{array}$ & $\begin{array}{l}\text { The high CEO-vega banks earned a larger } \\
\text { percentage of their incomes from non-interest } \\
\text { activities and invested a larger percentage of } \\
\text { their assets in private mortgage securitizations } \\
\text { and invested a smaller percentage of their } \\
\text { assets in on-balance-sheet business loan } \\
\text { portfolios. }\end{array}$ \\
\hline $\begin{array}{l}\text { Miencha and Selvam } \\
(2013)\end{array}$ & DEA & $\begin{array}{l}6 \text { Kenyan banks } \\
\text { for } 2007-11\end{array}$ & $\begin{array}{l}\text { Personnel } \\
\text { expenses, other } \\
\text { operating } \\
\text { expenses. }\end{array}$ & $\begin{array}{l}\text { Net-interest income, } \\
\text { Non-interest income. }\end{array}$ & $\begin{array}{l}\text { The managerial efficiency, off balance sheet } \\
\text { activities (non-traditional activities) and } \\
\text { profitability were the most influential } \\
\text { determinants of TE. }\end{array}$ \\
\hline $\begin{array}{l}\text { MINH, Long and Hung } \\
\text { (2013) }\end{array}$ & DEA- VRS & $\begin{array}{l}32 \text { Vietnam } \\
\text { commercial banks }\end{array}$ & $\begin{array}{l}\text { 1-Investments } \\
\text { 2-Deposits } \\
\text { 3-Labor }\end{array}$ & $\begin{array}{l}\text { 1-Income } \\
\text { 2-Interesta } \\
\text { 3-Loans } \\
\end{array}$ & $\begin{array}{l}\text { There was a small number of efficient banks } \\
\text { and there was scope for these sample banks to } \\
\text { improve their production efficiency. }\end{array}$ \\
\hline
\end{tabular}

Source: Compiled from various journals/ books as given in the reference.

The present study is unique because unlike others, we emphasized the effect of scale efficiency by using the BCC and CCR efficiency scores.

\section{Statement of the Problem}

The study of banking efficiency is important to policy makers, industry administrators and many others who rely on the banking sector. Public sector banks once dominated Kenyan Banking Industry. Now the situation has changed and technology and professional management have helped private sector banks to gain remarkable growth in the Banking Industry. The private sector banks play an important role in the development of the Kenyan Economy. Therefore, the present study investigates the efficiency of Kenyan Public Sector Banks and Private Sector Banks. Many firms in the service industry face the problem of not producing better results in terms of efficiency. During the last decade, continuous 
changes in regulation, technology up gradation and competition, have revolutionized the global financial services industry and Kenyan commercial banks are no exception. The efficiency in the operation of banks has become an important issue in Kenya. It is crucial to benchmark the efficiency of banks operating in Kenya and hence this study.

\section{Objective of the Study}

The objective of the present study is to measure and analyze the technical efficiency of Kenyan commercial banks.

\section{Hypothesis of the Study}

The following null hypothesis was framed and tested by the study

NH1: There is no significant difference in the efficiency level of Private and Public Sector Banks in Kenya.

\section{Research Methodology}

\subsection{Sample Selection}

As on March 31, 2012, there was a total of 45 banks- five Public Sector Banks, 28 Private Sector Banks and 12 Foreign Sector Banks in Kenya (Central Bank of Kenya - Bank Supervision Annual Report, 2011). For the purpose of this study, a population of twenty-two sample banks, which included five Public Sector Banks and seventeen Private Sector Banks, was chosen, based on their market capitalization as on March 31, 2013.

\subsection{Sources of Data}

This study was mainly based on secondary data. The required data were collected from annual reports of the Central Bank of Kenya, various reputed journals and respective bank websites. The informal feedback from a few customers and top managers of banks was also used to frame valuable suggestions.

\subsection{Period of Study}

The study period was from January 2010-11 to December 2012-13.

\subsection{Tools Used}

The Data Envelopment Analysis (DEA) is a performance measurement technique, used for analyzing the relative efficiency of productive units, having multiple inputs and multiple outputs. It is a non-parametric analytic technique which compares the relative efficiency of units by using a benchmark and by measuring the inefficiencies in input combinations in units relative to the benchmark. Farrell (1957) measured the technical efficiency of production input in a single output case. DEA was originally developed by Charnes Cooper and Rhodes (1978) with the assumption of constant return to scale. This study employed the CCR-Model by using the following formula.

Efficiency $=\frac{\text { Weighted sum of outputs }}{\text { Weighted sum of Inputs }}$

The weights for the ratio are determined by the restriction that similar ratios for every DMU have to be less than or equal to unity, thus reducing multiple inputs and outputs to a single virtual output without requiring pre-assigned weights. Therefore, the efficiency score is a function of the weights of the virtual input-output combination. The relative efficiency score of a given DMUo is obtained by solving the following linear programming model.

$\operatorname{maxh}{ }_{0}(u, v)=\frac{\sum_{r=1}^{s} v_{r} y_{r_{0}}}{\sum_{i=1}^{m} u_{r} x_{i_{0}}}$

Where,

$X_{i j}=$ the amount of input i utilized by the jth DMU

$Y_{r j}=$ the amount of output $r$ utilized by the jth DMU, and

$\mathrm{U}_{\mathrm{i}}=$ weight given to input $\mathrm{i}$.

The linear programming model, shown above, is run $n$ times for identifying the efficiency score of all the DMUs. Each DMU selects input weights that maximize its efficiency score. Generally, a DMU is considered to be efficient if it obtains a score of 1.00 , implying 100 percent efficiency whereas a score of less than 1.00 , implies that it is inefficient. It is 
to be noted that technical efficiency comprises pure technical efficiency and scale efficiency. This requires the estimation of the two DEA models - one with Constant Returns to Scale (CRS) and the other with Variable Returns to Scale (VRS). The model, with constant returns to scale, is known as the CCR Model. If there is difference in the two technical efficiency scores of a particular bank, it means that the bank's scale is inefficient (Ho and Zhu 2004). Data Envelopment Analysis Online Software (D.E.A.O.S) was used for the purpose of calculation of data for this study. Charnes Cooper and Rodhes (CCR) and Bankers Cooper Charnes (BCC) were the models used to measure the volatility of banks efficiency.

\section{Limitations of the Study}

The present study suffers from the following major limitations.

1. The study was based only on secondary data.

2. The study focused only on the productivity efficiency of sample banks.

3. Limitations associated with the tools used, are applicable to this study also.

4. It was limited to only two sectors of banks (Public and Private).

5. The period of the study was limited to only three years.

\section{Analysis of the Efficiency Measurement of Kenyan Commercial Banks}

For the purpose of this study, the analysis of efficiency measurement of sample commercial banks, functioning in Kenya, was made as follows:

8.1 Efficiency Measurement of Private Sector Banks and Public Sector Banks - 2011.

8.2 Efficiency Measurement of Private Sector Banks and Public Sector Banks - 2012.

8.3 Efficiency Measurement of Private Sector Banks and Public Sector Banks - 2013.

For the purpose of analysis of this study, the sample commercial banks taken for this study, were divided into two groups - Public Sector Banks and Private Sector Banks. The Public Sector included nine banks, namely, Consolidated Bank of Kenya, Development Bank of Kenya, National Bank of Kenya, K-Rep Bank, Kenya Commercial Bank, ABC Bank, Chase Bank, Bank of Africa and Credit Bank. The Private Sector covered 28 banks, namely, ABC Bank (Kenya), Citi Bank, Diamond Trust Bank, Dubai Bank Kenya, ECO bank, First Community Bank, Guaranty Trust Bank, Guardian Bank, I\&M Bank, NIC Bank, Paramount Universal Bank, Prime Bank (Kenya), Victoria Commercial Bank. It is to be noted that the sample banks, which effectively used their inputs and outputs, were considered to be efficient. In other words, the efficiency of a bank is determined by its weighted output, divided by the weighted input which ranges from zero to one (0 to 1.00). The score value of one indicates perfect efficiency of banks while the score less than one, indicates less efficient.

\subsection{Efficiency Measurement of Private Sector Banks and Public Sector Banks - 2011}

The efficiency score of sample public and private sector banks, (using Data Envelopment Analysis) for 2011 is reported in Table - 2. It is clear from the analysis of sample banks, as given in the Table that the input score of Kenyan commercial banks ranged between 0.994476 to 1.00 (private sector banks) and 0.974547 to 1.00 (public sector bank) in 2011. It is to be noted that there was only moderate efficient private sector bank (Barclays Bank of Kenya) which earned an efficiency score of 0.993923 in 2011. In other words, the Barclays Bank was required to improve its efficiency by a score of 0.006077 to be in the efficient frontier in 2011. Another private bank, namely, CFC Bank of Kenya, earned an efficiency score of 0.954776 and it required to earn additional score of 0.045224 in respect of input and the same amount of output to become efficient in 2011. Similarly, the Equity Bank of Kenya scored the efficiency value of 0.986906 and required to earn additional value of 0.013094 (input and the output) to be in the efficient frontier. One more sample bank namely, Victoria Bank of Kenya in the Private Sector earned a score of 0.991527 , which required to earn additional score of 0.008473 to become an efficient bank in 2011. It is to be noted that Diamond Trust Bank of Kenya earned a score of 0.990006 in 2011 and it required to take its input to the level of 0.00994 to become an efficient bank. It is significant that in 2011, ten sample banks, out of the 15 sample Private Sector Banks, were efficient. Those ten sample banks which earned an efficient score of 1.00 in 2011, included Commercial Bank of Africa, Co-operative Bank of Kenya, Equatorial Bank of Kenya, Family Bank of Kenya, Fidelity Bank of Kenya, Giro Bank of Kenya, Jamii Bora Bank of Kenya, Oriental Commercial Bank of Kenya, Trans National Bank of Kenya and United Bank of Africa.

On the other hand, out of the seven Public Sector Banks, six banks (Consolidated Bank of Kenya, Development Bank of Kenya, National Bank of Kenya, K-Rep Bank of Kenya, Chase Bank of Kenya and Credit Bank of Kenya) were efficient with a score of 1.00 . It is clearly understood from the above Table that the efficient score of 0.974547 was recorded for Kenya Commercial Bank, which needed a score of 0.025453 (i.e. the amount of the input and output) to be 
considered as the efficient bank. The moderate efficient public sector sample bank, namely, Barclays Bank of Kenya with an efficient score of 0.993923 was required to earn additional value of input and output, equivalent to a score of 0.006077 , to become an efficient unit.

According to the overall analysis of the Table, five sample Kenyan Private Sector Banks (Barclays Bank of Kenya 0.993923, CFC Bank of Kenya 0.954776, Equity Bank of Kenya - 0.986906, Victoria Commercial Bank - 0.991527 and Diamond Trust Bank - 0.990006) and one Kenyan Public Sector Bank (Kenya Commercial Bank - 0.974547) were moderately efficient in 2011. It is to be noted that one Private Bank, namely, CFC Bank of Kenya which earned a score of 0.954776, was required additional input and the same level of output equal to 0.045224 for considering it to be an efficient unit. In the same way, Equity Bank of Kenya, which earned 0.986906, was required an input and the same output score of 0.013094 to be an efficient bank. It is interesting to record that in 2011, the overall average score earned by all sample banks was 0.99540 which was considered a good score.

Chart - 1 gives the efficiency level of Public and Private Sector Banks in Kenya in 2011. The Chart clearly shows the fact that out of 22 sample banks, 19 of them (Commercial Bank of Africa, Cooperative Bank of Kenya, Equatorial Commercial Bank, Family Bank, Fidelity Commercial Bank, Giro Commercial Bank, Jamii Bora Bank, Oriental Commercial Bank, Trans National Bank of Kenya, United Bank of Africa, Consolidated Bank of Kenya, National Bank of Kenya, K-Rep Bank, Chase Bank and Credit Bank of Kenya) were efficient, with a score of 1.00 and there were six inefficient banks in 2011. Those sample banks were Barclays Bank of Kenya, CFC Bank of Kenya, Equity Bank of Kenya, Victoria Commercial Bank, Diamond Trust Bank and Kenya Commercial Bank of Kenya.

Table -2. Efficiency Measurements of Private Sector Banks and Public Sector Banks - 2011

\begin{tabular}{|c|l|c|c|}
\hline Serial No & Sample Banks & \multicolumn{2}{|c|}{ Score } \\
\hline A & Private Banks & 0.993923 & Input Inefficiency \\
\hline 1 & Barclays Bank of Kenya & 0.954776 & 0.006077 \\
\hline 2 & CFC Bank of Kenya & 1.000000 & 0.045224 \\
\hline 3 & Commercial Bank of Africa & 1.000000 & 0.000000 \\
\hline 4 & Cooperative Bank of Kenya & 1.000000 & 0.000000 \\
\hline 5 & Equatorial Commercial Bank & 0.986906 & 0.000000 \\
\hline 6 & Equity Bank of Kenya & 1.000000 & 0.013094 \\
\hline 7 & Family Bank of Kenya & 1.000000 & 0.000000 \\
\hline 8 & Fidelity Commercial Bank & 1.000000 & 0.000000 \\
\hline 9 & Giro Commercial Bank & 1.000000 & 0.000000 \\
\hline 10 & Jamii Bora Bank & 1.000000 & 0.000000 \\
\hline 11 & Oriental Commercial Bank & 1.000000 & 0.000000 \\
\hline 12 & Trans National Bank of Kenya & 1.000000 & 0.000000 \\
\hline 13 & United Bank for Africa & 0.991527 & 0.000000 \\
\hline 14 & Victoria Commercial Bank & 0.990006 & 0.008473 \\
\hline 15 & Diamond Trust Bank & 0.994476 & 0.009994 \\
\hline & Average Efficiency Score of Private Banks & \\
\hline & \multicolumn{2}{|c|}{ Input } \\
\hline B & Public Banks & Efficiency Level & Inefficiency \\
\hline 1 & Consolidated Bank of Kenya & 1.000000 & 0.000000 \\
\hline 2 & Development Bank of Kenya & 1.000000 & 0.000000 \\
\hline 3 & National Bank of Kenya & 1.000000 & 0.000000 \\
\hline 4 & K-Rep Bank & 1.000000 & 0.000000 \\
\hline 5 & Kenya Commercial Bank & 0.974547 & 0.025453 \\
\hline 6 & Chase Bank & 1.000000 & 0.000000 \\
\hline 7 & Credit Bank of Kenya & 1.000000 & 0.000000 \\
\hline & Average Efficiency Score of Public Banks & 0.996364 & \\
\hline & Overall Average Score & 0.99540 & \\
\hline & & & \\
\hline
\end{tabular}

Sources: Central Bank of Kenya publication for 2011-2013.

Note: The efficiency score was computed using Data Envelopment Analysis Software online version. 


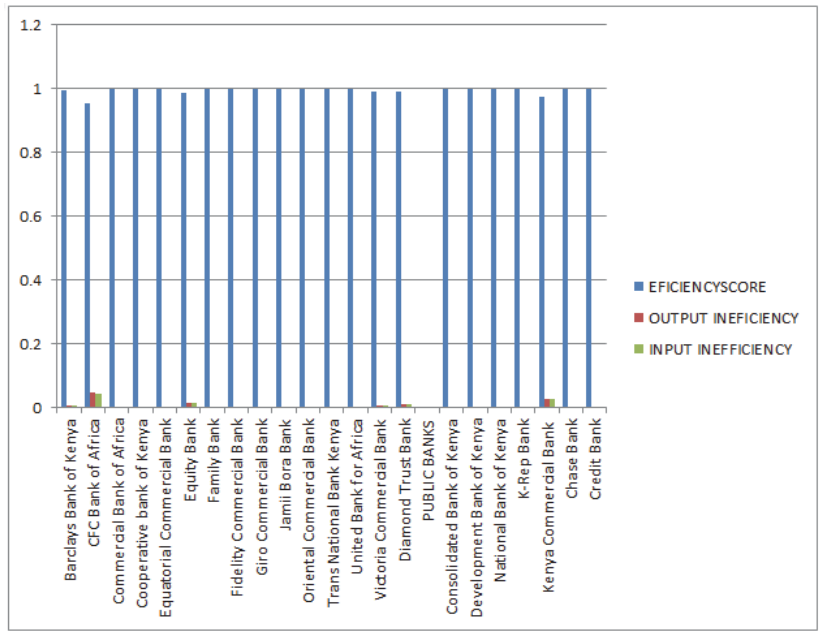

Chart -1. The level of Efficiency level of Sample Private Sector Banks and Public Sector Banks - 2011 Source: Computed from Table - 2

\subsection{Efficiency Measurement of Private Sector Banks and Public Sector Banks - 2012}

Table -3 gives the results of Data Envelopment Analysis (DEA) to determine the efficiency level of Public and Private Sector Banks in Kenya in 2012. According to the analysis of the Table, thirteen Private Sector Banks, considered for this study, included Barclays Bank of Kenya, Commercial Bank of Africa, Co-operative bank of Kenya, Equatorial Bank of Kenya, Family Bank of Kenya, Fidelity Bank of Kenya, Giro Bank of Kenya, Jamii Bora Bank of Kenya, Oriental Commercial Bank of Kenya, Trans National bank of Kenya, United Bank of Africa, Victoria Bank of Kenya and Diamond Trust Bank of Kenya. These thirteen banks earned a score of 1.00 in 2012. It is to be noted that CFC Bank, a private sector bank, earned an efficiency score of 0.970765 . It had an input inefficiency level of 0.029235 in 2012 . A score value of 0.957049 was earned by Equity Bank of Kenya which required to earn an input and same amount of output score of 0.042951 to be in efficient frontier.

According to the results of the Table, efficient Public Sector Banks in 2012 were Consolidated Bank of Kenya, Development Bank of Kenya, National Bank of Kenya, K-Rep Bank of Kenya, Chase Bank of Kenya and Credit Bank of Kenya, with an efficiency score of 1.00. The score for Kenya Commercial Bank, among the Public Sector Banks, was 0.970573. It had an input inefficiency score of 0.029427 in 2012.

The overall analysis of the Table shows that two sample banks (namely, CFC bank, Equity bank and Kenya Commercial bank) were required an input and the same amount of output to the tune of 0.300 to be in the efficient frontier. In order to overcome the inefficient condition, those inefficient sample banks need to maximize their output or productivity. Equatorial Commercial Bank earned 0.957049, which was less efficient, required an input and output score of 0.42951 to become an efficient bank. Kenya Commercial Bank, a public sector bank, earned a score of 0.970573 , which was less than efficient by 0.029427 . Kenyan Commercial Banks required to earn a score of 0.0300 , input and output to become an efficient bank. It is inferred from the Table that both sectors were doing well though some inefficiency was recorded. The Private Sector Banks earned an average efficiency score of 0.995188 while Public Banks earned an average efficiency score of 0.995796, with an overall average score of 0.995492 in 2012.

Chart - 2 clearly indicates the efficiency and the inefficiency level of sample Public and Private Sector Banks in 2012. It is interesting to note that six Public and 13 Private Sector Banks earned an absolute score of 1.00 and three sample banks (CFC Bank of Kenya, Equity Bank of Kenya and Kenya Commercial Bank) were inefficient and hence the line in the Chart was negative. Regarding input and output inefficiency, Equity Bank of Kenya recorded high input and output inefficiency while Kenya Commercial Bank accounted for less input and output inefficiency score. All the other sample banks were considered to be efficient in 2012. 
Table - 3. Efficiency Measurements of Private Sector Banks and Public Sector Banks- 2012

\begin{tabular}{|c|c|c|c|}
\hline Serial No & Sample Banks & \multicolumn{2}{|c|}{ Score } \\
\hline A & Private Banks & Efficiency Level & Input Inefficiency \\
\hline 1 & Barclays Bank of Kenya & 1.000000 & 0.000000 \\
\hline 2 & CFC Bank of Kenya & 0.970765 & 0.029235 \\
\hline 3 & Commercial Bank of Africa & 1.000000 & 0.000000 \\
\hline 4 & Cooperative Bank of Kenya & 1.000000 & 0.000000 \\
\hline 5 & Equatorial Commercial Bank & 0.957049 & 0.042951 \\
\hline 6 & Equity Bank of Kenya & 1.000000 & 0.000000 \\
\hline 7 & Family Bank of Kenya & 1.000000 & 0.000000 \\
\hline 8 & Fidelity Commercial Bank & 1.000000 & 0.000000 \\
\hline 9 & Giro Commercial Bank & 1.000000 & 0.000000 \\
\hline 10 & Jamii Bora Bank & 1.000000 & 0.000000 \\
\hline 11 & Oriental Commercial Bank & 1.000000 & 0.000000 \\
\hline 12 & Trans National Bank of Kenya & 1.000000 & 0.000000 \\
\hline 13 & United Bank for Africa & 1.000000 & 0.000000 \\
\hline 14 & Victoria Commercial Bank & 1.000000 & 0.000000 \\
\hline \multirow[t]{2}{*}{15} & Diamond Trust Bank & 1.000000 & 0.000000 \\
\hline & Average Efficiency Score of Private Banks & 0.995188 & \\
\hline B & Public Banks & Efficiency Level & Input Inefficiency \\
\hline 1 & Consolidated Bank of Kenya & 1.000000 & 0.000000 \\
\hline 2 & Development Bank of Kenya & 1.000000 & 0.000000 \\
\hline 3 & National Bank of Kenya & 1.000000 & 0.000000 \\
\hline 4 & K-Rep Bank & 1.000000 & 0.000000 \\
\hline 5 & Kenya Commercial Bank & 0.970573 & 0.029427 \\
\hline 6 & Chase Bank & 1.000000 & 0.000000 \\
\hline \multirow[t]{3}{*}{7} & Credit Bank of Kenya & 1.000000 & 0.000000 \\
\hline & Average Efficiency Score of Public Banks & 0.995796 & \\
\hline & Overall Average Score & 0.995492 & \\
\hline
\end{tabular}

Sources: Central Bank of Kenya publication 2011-2013.

Note: The efficiency score was computed using Data Envelopment Analysis Software online version.

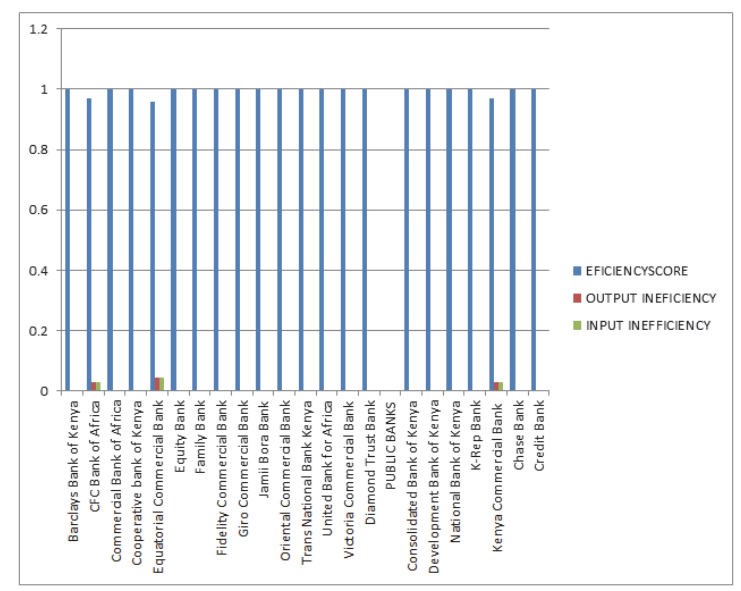

Chart -2. The level of Efficiency level of Sample Private Sector Banks and Public Sector Banks - 2012 Source: Computed from Table -3

\subsection{Efficiency Measurement of Private Sector Banks and Public Sector Banks - 2013.}

The results of Data Envelopment Analysis (DEA) to determine the efficiency level of Public Sector Banks and Private Sector Banks in 2013 are given in Table - 4. According to the analysis of the Table, efficient Private Sector Sample Banks included Barclays Banks of Kenya (1.00), CFC Bank of Africa (1.00), Commercial Bank of Africa (1.00), 
Cooperative Bank of Kenya (1.00), Equatorial Bank of Kenya (1.00), Family Bank (1.00), Fidelity Commercial Bank (1.00), Giro Commercial Bank (1.00), Jamii Bora Bank (1.00), Oriental Commercial Bank (1.00), Trans National Bank (1.00), United Bank of Africa (1.00), Victoria Commercial Bank (1.00) and Diamond Trust Bank (1.00). It is to be noted that one sample private sector bank, namely Equity Bank from all sample Private Sector Bank earned the less efficient score of 0.900869 in 2013.

It is to be noted that out of seven public sector banks, three Banks, namely National Bank (1.00), K-Rep Bank (1.00), and Kenya Commercial Bank (1.00) were efficient. But the score earned by Development Bank of Kenya, from the Public Sector Bank, was only 0.980123 , which was satisfactory but there was little scope to reach its efficiency level. The zero value in the input inefficiency column indicates that these banks (National bank, K-Rep Bank of Kenya, Kenya Commercial Bank, Chase Bank of Kenya and Credit Bank of Kenya) were not weak in input and output in 2013.

It is found from the overall analysis of the Table that three sample banks (namely, Equity bank of Kenya, Consolidated bank of Kenya and Development bank of Kenya) were weak in output (inefficiency). In order to overcome inefficiency, these sample banks need to maximize their output to the level of 1.00. It is interesting to note that the input inefficiency score, together for all the sample banks, was 0.02028. All the Private Sector Banks earned an average efficiency score of 0.993391 in 2013 while the average efficiency level of all Public Sector Banks was 0.923365, with an overall average score of 0.958378 for all sample banks in 2013.

Chart -3 clearly shows the efficiency level of Public Sector Banks and Private Sector Banks as well as their input and output inefficiency score for 2013. It is clearly inferred that three Public Sector Banks and fourteen Private Sector Banks were efficient, with the score value of 1.00. The Chart indicates that only five banks, namely, Equity Bank, Consolidated bank of Kenya, Chase bank, Credit Bank of Kenya and Development Bank of Kenya were inefficient, with values of $0.900869,0.68452,0.92541,0.8735$ and 0.980123 respectively. Regarding the input inefficiency, one bank, namely, Equity Bank received high input score of 0.099131 while Development bank accounted for less input score of 0.019877 (moderately by efficient) in 2013. All the other sample banks were considered efficient in 2013.

Table - 4. Efficiency Measurements of Private Sector Banks and Public Sector Banks - 2013

\begin{tabular}{|c|c|c|c|}
\hline Serial No & Sample Banks & \multicolumn{2}{|c|}{ Score } \\
\hline $\mathrm{A}$ & Private Banks & Efficiency Level & Input Inefficiency \\
\hline 1 & Barclays Bank of Kenya & 1.000000 & 0.000000 \\
\hline 2 & CFC Bank of Kenya & 1.000000 & 0.000000 \\
\hline 3 & Commercial Bank of Africa & 1.000000 & 0.000000 \\
\hline 4 & Cooperative Bank of Kenya & 1.000000 & 0.000000 \\
\hline 5 & Equatorial Commercial Bank & 1.000000 & 0.000000 \\
\hline 6 & Equity Bank of Kenya & 0.900869 & 0.099131 \\
\hline 7 & Family Bank of Kenya & 1.000000 & 0.000000 \\
\hline 8 & Fidelity Commercial Bank & 1.000000 & 0.000000 \\
\hline 9 & Giro Commercial Bank & 1.000000 & 0.000000 \\
\hline 10 & Jamii Bora Bank & 1.000000 & 0.000000 \\
\hline 11 & Oriental Commercial Bank & 1.000000 & 0.000000 \\
\hline 12 & Trans National Bank of Kenya & 1.000000 & 0.000000 \\
\hline 13 & United Bank for Africa & 1.000000 & 0.000000 \\
\hline 14 & Victoria Commercial Bank & 1.000000 & 0.000000 \\
\hline \multirow[t]{2}{*}{15} & Diamond Trust Bank & 1.000000 & 0.000000 \\
\hline & Average Efficiency Score of Private Banks & 0.993391 & \\
\hline B & Public Banks & Efficiency Level & Input Inefficiency \\
\hline 1 & Consolidated Bank of Kenya & 0.684520 & 0.31204 \\
\hline 2 & Development Bank of Kenya & 0.980123 & 0.019877 \\
\hline 3 & National Bank of Kenya & 1.000000 & 0.000000 \\
\hline 4 & K-Rep Bank & 1.000000 & 0.000000 \\
\hline 5 & Kenya Commercial Bank & 1.000000 & 0.000000 \\
\hline 6 & Chase Bank & 0.925410 & 0.000000 \\
\hline \multirow[t]{3}{*}{7} & Credit Bank of Kenya & 0.873500 & 0.000000 \\
\hline & Average Efficiency Score of Public Banks & 0.923365 & \\
\hline & Overall Average & 0.958378 & \\
\hline
\end{tabular}

Sources: Central Bank of Kenya publication for 2011-2013.

Note: The efficiency score was computed using Data Envelopment Analysis Software online version. 


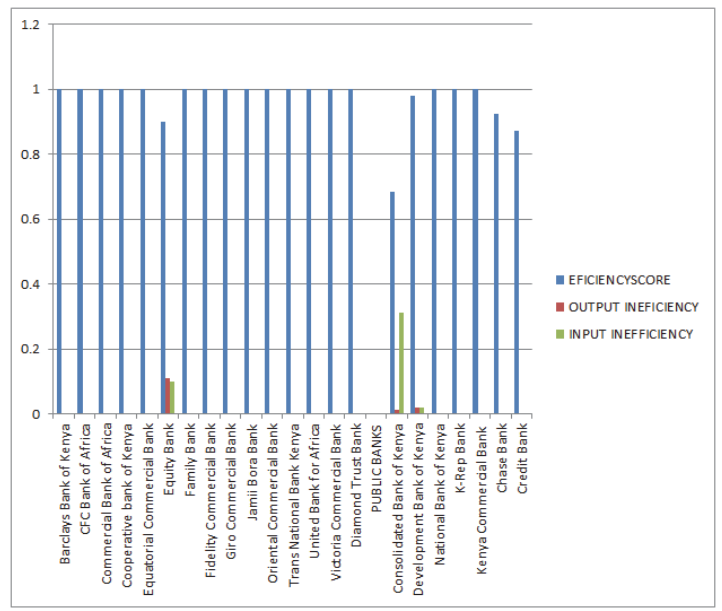

Chart -3. The level of Efficiency level of Sample Private Sector Banks and Public Sector Banks - 2013

Source: Computed from Table - 4

\section{Discussion and Conclusion}

An attempt has been made to investigate the efficiency of Kenyan Public and Private Sector Banks. The analysis of this confirmed that some sample banks were underperforming during the study period. To improve the efficiency of the banks, a number of policy measures at the bank level and country level are required. From the informal discussion with the bank officials and the representatives of Kenyan Government officials, it is suggested that the Government policy may include encouraging competition, greater use of technology, product diversification and restructuring of banks, followed by mergers etc. Sample banks in Kenya may have to be well equipped with state of the art information technology, strong human resource team and well-trained and highly motivated employees who can help the banks reach newer heights in the global scenario. In short, the efficiency of Kenyan Commercial Banks should be improved by putting all round efforts in line with global standards.

It is relevant to suggest, based on the informal feedback from a few customers and senior managers of banks, that all the banks need to implement the policy of 'Know Your Customer,' that would help the Kenyan banks to improve the quality of banking service, thereby enhancing the profitability, recovering the loans and decreasing the risks in operations. Secondly, it is better to provide banking services, through Self Help Groups, by identifying suitable and committed persons and thus enabling the banks in Kenya to save enormous human and monetary expenses. Finally, officials have to interact with people and customers for explaining bank products and services. The customers are to be educated that Kenyan banks are primarily committed towards development of people rather than merely making profits.

A similar study, conducted by Rajput and Gupta (2011), found that the efficiency of the Indian Banking Sector was at the score level above 0.800. The Public Sector Banks were found to be more efficient than the Private Sector Banks. Paul and Kourouche (2008) did similar study and evaluated 10 Australian banks on their technical efficiencies and found that the extent of technical efficiency varied across the banks and over the years. Debnath and Ravishankar (2008) used the models of BCC and CCR Models over 50 Indian banks and examined the efficiency of banks in India. The findings of the present study are in line with the above studies. Miencha, et al (2013) analyzed the relative efficiency of sample commercial banks in Kenya. The relative average efficiency score, by applying data envelopment analysis (BCC and CCR Models), for ten sample banks which earned 65.66 percent, was considered to be moderately efficient. It is to be noted that the sample banks considered for this study were inefficient during the study period.

\section{References}

Andrew C. Worthington (1998), The Determinants of Non-Bank Financial Institution Efficiency: A Stochastic Cost Frontier Approach. Applied Financial Economics, 8, $279-287$.

Asmild, M., J.C Parad, and Kulkarni, A. (2006), Using Data Envelopment Analysis in Software Devleopmet Productivity Measurement, 
Software Process: Improvement and Practice, 11 (3), 561-572.

Arabinda Saha (2008) Performance Indicators of Banking Sector in Bangladesh: A Comparative Study Overview of NCB, PCB, and FCB, SMART J. of Business Management Studies, 4 (1), 1- 9.

Avkran, N.K. and Rowlands, T. (2008), How To Better Identify The True Managerial Performance: State of the Art Using DEA, Omega (Elsevier), 36(1), 317-324.

Banker, R. D., Charnes, A. W, and Cooper, W. W. (1984), Some Models For Estimating Technical and Scale Inefficiencies in Data Envelopment Analysis, Management Science, 30(9), 1078-1092.

Charnes, A., Cooper, W. W., and Rhodes, E. (1978). Measuring the Efficiency of Decision-making Units. European Journal of Operational Research, 2(2), 429-444.

David A. Grigorian and Vlad Manole (2002), Determinants of commercial Bank Performance in Transition: An Application of Data Envelopment Analysis, World Bank Policy Research Working paper No. 2850.

Dan Luo and Shujie Yao (2010), World Financial Crisis and the rise of Chinese Commerce Banks: An Efficiency Analysis using DEA. Applied Financial Economics 20, $1515-1530$.

Debasish, S.S. (2006), Efficiency Performance in Indian Banking: Use of Data Envelopment Analysis, Global Business Review, 7(2), 325-333.

Debnath, R.M., and Ravishankar (2008), Measuring Performance of Indian Banks: An Application Data Envelopment Analysis, Journal of Business Performance Management, 10(1), 57-85.

DeYoung, R., Peng, E. Y., and Yan, M. (2013). Executive Compensation and Business Policy Choices at US Commercial Banks. Journal of Financial and Quantitative Analysis, 48(01), 165-196.

Farrell M. J. (1957) The Measurement of Productive Efficiency, Journal of the Royal Statistical Society. Series A (General), 120, (3), 253 $-290$.

Fadzlan Sufian and Muzafar Shah Habibullah (2010), Developments in the Efficiency of the Thailand Banking Sector: a DEA Approach, International journal of Development 9(3), $226-245$.

Ho, C., and Zhu, D.S. (2004). Performance Measurement of Taiwan's Commercial Banks. International Journal of Productivity and Performance Management 53(5), 425-434.

Isaiah Onsarigo Miencha and Murugeresan Selvam, (2011), The Performance Efficiency of Commercial Banks in Kenya, Competency Building Strategies in Business and Technology, 5th ed. 945- 952.

Isaiah Onsarigo Miencha and Murugesan Selvam (2013), Financial Performance in the Banking Sector: A Study With Special Reference to Kenyan Commercial Banks Using Data Envelopment Analysis (DEA). Research Journal of Social Science and Management 2 (8), $48-53$.

Isaiah Onsarigo Miencha, Murugesan Selvam, Rajesh Ramkumar, and Karpagam Venkantraman (2013), Relative Efficiency of Kenyan Commercial Banks, International Business Management 7(3), 142-150.

King and Levine, (1993) Finance and Growth: Schumpeter Might be Right, The Quarterly Journal of Economics, 108(3), 717-737.

Kumar, Sunil and Rachita Gulati (2008), Evaluation of Technical Efficiency and Ranking of Public-Sector Banks in India, International J. of Productivity and Performance Management, 57, (7), 540-568.

Kyriaki Kosmidou and Constantin Zopounidis (2008), Measurement of Bank Performance in Greece South-East Europe Journal of Economics 1 (2008) 79 - 95.

Minh, Long and Hung (2013), Efficiency and Super-Efficiency of Commercial Banks in Vietnam: Performances and Determinants. AsiaPacific Journal of Operational Research, 30(1), 1250047-1 to 1250047-19.

Mkandawire, T. (1999). The Political Economy of Financial Reform in Africa. Journal of International Development, 11, 321-342.

Nissanke, M., \& Stein, H. (2003). Financial Globalization and Economic Development: Toward an Institutional Foundation. Eastern Economic Journal, 29(2), 287-308.

Paul, S., and Kourouche, K. (2008). Regulatory Policy and the Efficiency of the Banking Sector in Australia. Australian Economic Review, 41(3), 260-271.

Rajput, N., and Gupta, M. (2011). Efficiency of Public Sector Banks Operating in India: Post-Reforms Period Analysis. Afro-Asian J. of Finance and Accounting 2(4), $349-368$.

Robert DeYoung and Iftekhar Hasan (1998), The Performance of De Novo Commercial banks: A Profit Efficiency Approach, Journal of Banking and Finance, 22, $565-587$.

Satya Paul and Khaled Kourouche (2008), Regulatory Policy and Efficiency of the Banking Sector in Australia, Australian Economic Review 41 (3) $260-271$.

Supachet Chansan (2008), Relative Efficiency of Commercial Banks in Thailand: DEA Approach, International Research Journal of Finance and Economics. 18: $53-68$.

Tser-Yieth Chen and Tsai-Lien Yeh (2000), A Measurement of Bank Efficeincy, Ownership and Productivity Changes in Taiwan. The Service Industries Journal, 20 (1), 95 - 109.

Wang and Huang (2005), Measuring the Relative Efficiency of Commercial Banks: A Comparative Study on Different Ownership Modes in China, The Journal of American Academy of business, Cambridge. 7 (2), 219 - 293.

\section{Website}

www.centralbankofkenya.co.ke (Central Bank of Kenya - Supervision Annual Report 2013) 